\title{
Protection of Clinical Test Data and Public Health: A Proposal to End the Stronghold of Data Exclusivity
}

\author{
Ellen 't Hoen
}

\begin{abstract}
Test data demonstrating the efficacy, safety and quality of a medicine is required by drug regulatory agencies before a new treatment obtains marketing approval and can be made available to patients. Because test data can be costly and time-consuming to produce, certain countries have 'data exclusivity' regimes that restrict use of test data to the originator company for a period of time. Generic and biosimilar companies rely on originator test data to obtain marketing approval for generic products, so data exclusivity periods can delay entry of lower-cost treatments to the market. While data exclusivity is not required by the World Trade Organization, countries such as the United States and the European Union often push their stronger data exclusivity provisions on other countries through free trade agreements (FTAs). While a small number of countries have waivers to data exclusivity for cases of emergency or other public health need, most do not. This can hamper the timely and affordable availability of needed medicines. Waivers to data exclusivity should be included in legislation to protect public health, and other ways to protect test data against unfair commercial use should be explored.
\end{abstract}

\section{Introduction: Test Data and Efficacy, Safety and Quality of Medicines}

Assuring the efficacy, safety and quality of medicines-be it of originator products or generic medicines - is an important public function meant to protect the health of consumers and patients. This function is performed by national or regional medicines regulatory agencies, such as the US Food and Drug Administration (FDA) and the European Medicines Agency (EMA), using the data that is submitted to the agency by companies that seek to obtain a marketing authorisation for a medicinal product. For new medicines, medicines regulatory agencies require drug companies to submit test data that demonstrates efficacy, safety and quality of the medicine

\footnotetext{
E. 't. Hoen $(\bowtie)$

Medicines Law \& Policy, Amsterdam, The Netherlands

e-mail: ellenthoen@medicineslawandpolicy.net 
before granting marketing authorisation. Generating such data can be timeconsuming and costly, particularly when it involves a new chemical entity or a new biologic medicine. As a result, test data is often protected against use by others. The TRIPS Agreement (Article 39.3) requires the protection of certain kinds of test data against unfair commercial use but does not require to provide exclusive rights to such data. In certain jurisdictions the protection of test data takes the form of data exclusivity; data exclusivity means that the use of the test data is exclusive to the originator company for a certain period of time. In practical terms, this means that during the data exclusivity period a generic version of the product cannot be registered by the regulatory agency.

\section{Generic and Biosimilar Medicine Marketing Approval and the Use of Test Data}

A generic company applying for marketing authorisation for a generic product has to demonstrate that its product is bioequivalent to the originator product. Importantly, the generic applicant is not required to generate its own clinical efficacy and safety data. The generic applicant can rely on the clinical test data that was submitted by the original applicant, and which is on file with the regulatory agency. Applicants for biosimilar medicines (generic biologic medicines) have to demonstrate biosimilarity (analogue to bioequivalence for biologic medicines) and can also rely on the safety and efficacy experience gained with the reference medicine. ${ }^{1}$ This avoids unnecessary repetition of clinical trials already carried out with the reference medicine.

Data exclusivity regimes delay the use of existing test data by generic and biosimilar companies in seeking marketing approval for their medicines for as long as the data exclusivity period holds. ${ }^{2}$

Data exclusivity does not prohibit the generic or biosimilar company from generating its own clinical efficacy data, but this is costly and, in most cases, would raise serious ethical issues. Such tests would involve carrying out randomised controlled clinical trials in which an already proven effective treatment is withheld from part of the study participants who receive the comparator or placebo product. In reality, generic companies do not carry out such trials. Therefore, a data exclusivity regime creates strong monopolies that are automatically granted, quietly enforced by the medicines regulatory system and often without exceptions or limitations.

\footnotetext{
${ }^{1}$ European Medicines Agency and the European Commission, Biosimilars in the EU: Information guide for healthcare professionals (European Medicines Agency, 2019) https://www.ema.europa. eu/en/documents/leaflet/biosimilars-eu-information-guide-healthcare-professionals_en.pdf.

${ }^{2}$ Technopolis (15 June 2018a). https://www.technopolis-group.com/report/effects-of-supplemen tary-protection-mechanisms-for-pharmaceutical-products/.
} 


\section{Rationale for Data Exclusivity}

The notion behind data exclusivity is that the production of clinical test data-by running, for example, clinical trials-requires significant investments. Protecting such test data against use by generic and biosimilar companies is thus seen as a means to encourage medical research and development $(R \& D)$. The rationale behind data exclusivity is similar to the rationale behind patents and other pharmaceutical market exclusivities: the assumption that the protection of the research and development investments that companies make by providing exclusive rights is needed and sufficient to stimulate innovation.

\subsection{Data Exclusivity and Patents}

There are important differences between data exclusivity regimes and patents. Data exclusivity is granted automatically and enforced through the regulatory system; the holders of the rights, mostly drug companies, do not have to apply or provide evidence of eligibility. Patent applications, by contrast, are examined before market exclusivities are granted; rights holders must demonstrate their product meets patentability criteria such as novelty, usefulness and inventive step. Most medicines laws that provide for data exclusivity do not provide for a waiver of it should it be necessary for public interest grounds to suspend the exclusivity. For patents, compulsory licences and other measures to circumvent exclusivity can be sought when there is a public health need (see also Sect. 6).

Data exclusivity rights exist independently of patents, can overlap with patents and can also exist where patents do not. Data exclusivity is also different from patents in that there is no international obligation to provide data exclusivity.

\subsection{Data Exclusivity's Effectiveness in Stimulating Innovation}

Whether data exclusivity is an effective or necessary measure to stimulate innovation is questionable at best. A publication by Dutch research group Technopolis, prepared upon request of the Dutch government that looked at pharmaceutical exclusivity incentives available to industry in the $\mathrm{EU}^{3}$ concluded "this study cannot provide any evidence on whether, or to what extent, the impacts of these exclusivities and protections align with the intended objectives." In 2009, the US Federal Trade Commission (FTC) concluded that a lengthy exclusivity period of

\footnotetext{
${ }^{3}$ Technopolis (May 2018b) http://www.technopolis-group.com/wp-content/uploads/2018/06/2718Technopolis-report-on-supplementary-protection-mechanisms.pdf.
} 
12-14 years is unnecessary to promote innovation by biologic drug manufacturers. The FTC considered existing incentives (patents and market-based pricing) to be sufficient to support biologic innovation. ${ }^{4}$ In 2016, the EU Council decided to carry out an assessment of the various pharmaceutical incentive mechanisms contained in EU regulations with a view "to strengthen the balance in the pharmaceutical systems in de EU and its Member States." This review is ongoing but preliminary reports indicate that evidence is ambiguous at best. ${ }^{5,6,7}$

\section{History of Data Exclusivity}

\subsection{Data Exclusivity in the United States}

Data exclusivity was first introduced in the US in 1984 when the "Drug Price Competition and Patent Term Restoration Act of 1984," also known as the "Hatch-Waxman Amendments" was adopted. The act provided several types of exclusivities to innovators, in addition to patents, as a trade-off for provisions to make market entry of generics easier and quicker. ${ }^{8}$ The US provides 5 years of data exclusivity for small molecule new chemical entities; 3 years for a new indication of a previously approved medicine; and 4 years for biologics, complemented by a parallel 12-year market exclusivity. ${ }^{9}$

\subsection{Data Exclusivity in the European Union}

The EU introduced data exclusivity in 1987 . Directive $87 / 21 /$ EEC initially provided for 6 years of data exclusivity for most medicines, and 10 years for biotechnology products, both measured from the date of first marketing approval. Member states

\footnotetext{
${ }^{4}$ Federal Trade Commission (June 2009) https://www.ftc.gov/sites/default/files/documents/reports/ emerging-health-care-issues-follow-biologic-drug-competition-federal-trade-commission-report/ p083901biologicsreport.pdf.

${ }^{5}$ Council of the EU, 'Council conclusions on strengthening the balance in the pharmaceutical systems in the EU and its Member States' (17 June 2016) https://www.consilium.europa.eu/en/ press/press-releases/2016/06/17/epsco-conclusions-balance-pharmaceutical-system/.

${ }^{6}$ Copenhagen Economics, Study on the economic impact of supplementary protection certificates, pharmaceutical incentives and rewards in Europe (European Commission, May 2018) https://ec. europa.eu/health/sites/health/files/human-use/docs/pharmaceuticals_incentives_study_en.pdf.

${ }^{7} \mathrm{https}: / /$ medicineslawandpolicy.org/useful-resources/briefs/.

${ }^{8}$ Lietzan (2016), p. 91 https://pdfs.semanticscholar.org/2fdb/0784f6fb314cf99063933cb6bfbfae6a7091. pdf.

${ }^{9}$ U.S. Federal Trade Commission (FTC, June 2009). https://www.ftc.gov/reports/emerging-healthcare-issues-follow-biologic-drug-competition-federal-trade-commission-report.
} 
could extend data exclusivity to 10 years if they considered this was "in the interest of public health." Member states had different views as to when an extension to 10 years was justified, which led to a variation in exclusivity periods throughout the EU. In 2004, the EU data exclusivity rules were further harmonised and extended to 8 years of data exclusivity, plus two additional years of market exclusivity during which generic companies can prepare and apply for their marketing approval using test data but not market the product. An additional 1 year of market exclusivity can be obtained by the originator company for a new indication with significant added clinical benefit. ${ }^{10}$ The new EU exclusivity regime became known as the $8+2+1$ rule. The EU data exclusivity regime is the most generous in the world.

\subsection{Protection of Test Data and the Rules of the World Trade Organization}

During the Uruguay Round negotiations on intellectual property, the option of making data exclusivity an explicit obligation under the Agreement on TradeRelated Aspects of Intellectual Property Rights (TRIPS Agreement) ${ }^{11}$ was discussed, but the TRIPS negotiators explicitly rejected language that would have required granting exclusive rights to test data, opting for the more general text of Article $39.3,{ }^{12}$ which reads as follows:

Members, when requiring, as a condition of approving the marketing of pharmaceutical or of agricultural chemical products which utilize new chemical entities, the submission of undisclosed test or other data, the origination of which involves a considerable effort, shall protect such data against unfair commercial use. In addition, Members shall protect such data against disclosure, except where necessary to protect the public, or unless steps are taken to ensure that the data are protected against unfair commercial use.

The WTO TRIPS Agreement contains an obligation of WTO members to protect certain kinds of test data against unfair commercial use, but does not create an obligation to provide data exclusivity. TRIPS data protection against unfair commercial use is required only where that data is related to a new chemical entity and required as a condition of marketing approval, was previously undisclosed, and required considerable effort to generate. Importantly, TRIPS does not stipulate a time period for this protection. This is further evidence of the absence of a data exclusivity obligation.

\footnotetext{
${ }^{10}$ Directive 2004/27/EC on the Community code relating to medicinal products for human use [2004] OJ L136/34.

${ }^{11}$ Agreement on Trade-Related Aspects of Intellectual Property Rights (Apr. 15, 1994) (hereinafter TRIPS Agreement).

${ }^{12}$ The World Health Organization (WHO), the World Intellectual Property Organization (WIPO) and the World Trade Organization (WTO), WHO (2012), p. 64. https://www.wipo.int/policy/en/ global_health/trilateral_cooperation.html.
} 
TRIPS also does not preclude the use of test data for the regulatory approval of a competing product, which, as some have argued, does not fall within the definition of 'unfair commercial use'. ${ }^{13,14,15}$ This position was reiterated by the developing country members of the WTO in 2001 at the Doha Ministerial Conference, where they stated that article 39.3 of TRIPS “does not require granting 'exclusive rights' to the owner of the data" and that it "does permit a national competent authority to rely on data in its possession to assess a second and further applications, relating to the same drug, since this would not imply any "unfair commercial use'."16 TRIPS also does not require WTO members to extend protection to data that is in the public domain. $^{17}$

The obligation to protect test data against 'unfair commercial use' does not yet apply to least developed country members (LDCs) of the WTO, who do not need to implement pharmaceutical-related aspects of the TRIPS agreement until 2033 or until they cease to be LDCs. ${ }^{18}$

Today, most WTO members, outside the EU or the United States, do not provide data exclusivity. A survey of MedsPaL, ${ }^{19}$ a database of select medicines patent and exclusivity status, shows that only around 16 middle-income countries provide data exclusivity. Data exclusivity regimes often find their origin in trade agreements with the EU or the US that were negotiated outside of the WTO (see Sect. 5).

In conclusion, the TRIPS Agreement gives countries considerable latitude as to how they want to implement test data protection.

\footnotetext{
${ }^{13}$ Reichman (2009), p. 17.

${ }^{14}$ Timmermans (2007), p. e2.

${ }^{15}$ Commission on Intellectual Property Rights, Innovation and Public Health, Public Health, Innovation and Intellectual Property Rights (World Health Organization, 2006).

${ }^{16}$ 'TRIPS Council Discussion on Access to Medicines: Developing Country Group's Paper' (World Trade Organization, 20 June 2001) IP/C/W/296, paras 39-40. https://www.wto.org/english/tratop_ e/trips_e/paper_develop_w296_e.htm.

${ }^{17}$ Correa (2002). https://www.southcentre.int/wp-content/uploads/2019/02/Bk_2002_Protectionof-Data-Submitted-for-Pharmaceuticals-Registration_EN.pdf.

${ }^{18}$ The Council for Trips Extension of the Transition Period Under Article 66.1 of the Trips Agreement for Least Developed Country Members for Certain Obligations with Respect to Pharmaceutical Products (6 November 2015), World Trade Organization IP/C/73.

19 'MedsPaL: The Medicines Patents and Licences Database'. https://www.medspal.org.
} 


\section{Data Exclusivity in Free Trade Agreements (FTAs)}

The obligation to grant data exclusivity to the originator company in the US and the EU goes beyond the requirement of the TRIPS Agreement ${ }^{20}$ for the protection of undisclosed test data against unfair commercial use. Both the US and the EU seek to globalise their data exclusivity norms through trade agreements, including in WTO accession agreements with other countries or in bilateral agreements or trading blocs, by demanding from their trading partners that they introduce or expand data exclusivity.

In recent FTAs there has been some roll back of the demands related to data exclusivity. In 2018, after the withdrawal of the US, the 11 remaining parties to the Comprehensive and Progressive Agreement for Trans-Pacific Partnership (CPTPP, formerly the TPP) suspended the IP chapter, including its various market exclusivity obligations. The US-Mexico-Canada Agreement (USMCA) initially contained a provision that bound parties to 5-year exclusivity for small molecules, 3 years for new clinical information (new use of a known medicine), and 10-years for biologics. In 2019, driven by the debate on high drug prices in the US, the provision for 10-year exclusivity for biologics was removed from the USMCA.

\section{Data Exclusivity and TRIPS Flexibilities}

The TRIPS Agreement includes a number of flexibilities that are relevant for public health. Data exclusivity can form a serious barrier to the effective use of such flexibilities for the purpose of accessing lower priced medicines. In particular, the effectiveness of compulsory licensing - a mechanism whereby a government grants third parties or itself the right to use a patented innovation without the consent of the patent holder-may be muted by data exclusivity.

\subsection{Compulsory Licensing and Government Use in Drug Procurement}

When a government grants itself the right to make use of a patented innovation through a compulsory licence, this is often called 'government use', or 'public non-commercial use'. ${ }^{21}$ Such compulsory licences can be particularly useful in

\footnotetext{
${ }^{20}$ During the Uruguay Round negotiations, the option of making data exclusivity an explicit obligation under the TRIPS Agreement was discussed, but negotiators instead adopted the general wording of the current Article 39.3. See: WTO, WIPO, and the WHO (n 10).

${ }^{21}$ This chapter will further use the term 'compulsory licence' to refer to both compulsory licences and government use or public non-commercial use of a patent.
} 
public procurement of medicines to access lower-priced medicines from generic competitors.

The government is free to determine the grounds for granting a compulsory licence. Some countries' domestic laws include specific provisions such as 'high prices' of medicines, or a 'lack of access to medicines'. For example, French patent law authorises government use upon request by the minister of health when medicines are 'only available to the public in insufficient quantity or quality or at abnormally high prices.' 22

In 2001 the WTO Doha Declaration on the TRIPS agreement and Public Health ${ }^{23}$ provided a welcome clarification of the flexibilities ${ }^{24}$ contained in the TRIPS Agreement for the purpose of public health and specifically 'to promote access to medicines for all'. ${ }^{25}$ Against the background of trade pressure on low- and middleincome countries that contemplated the use of compulsory licensing and other TRIPS-flexibilities, the Doha Declaration took away any doubts about the legality of such measures. Subsequently, low- and middle-income countries have used TRIPS flexibilities on a large scale in particular but not exclusively to facilitate the supply of low-cost generic medicines used for the treatment of HIV. ${ }^{26}$

\subsection{Data Exclusivity and Compulsory Licensing}

Countries that have a data exclusivity regime may find providing more affordable access to a patent-protected medicine through a compulsory licence is hindered if the originator company's product benefits from data exclusivity. While a compulsory licence may open the possibility of providing generic versions of a medicine that is still patent protected, data exclusivity may prevent the registration of such generic medicines and therefore still block their entry into the market.

\footnotetext{
${ }^{22}$ Code de la propriété intellectuelle (version consolidée au 9 octobre 2016) Article L613-16.

${ }^{23}$ Declaration on the TRIPS agreement and public health (14 November 2001) WT/MIN(01)/DEC/

2. https://www.wto.org/english/thewto_e/minist_e/min01_e/mindecl_trips_e.htm (hereinafter Doha Declaration).

${ }^{24}$ The term 'flexibilities' is used to describe limitations and exceptions to exclusive rights that countries can deploy for reasons of public interest. See also: WIPO, 'Meaning of Flexibilities'. http://www.wipo.int/ip-development/en/agenda/flexibilities/meaning_of_flexibilities.html.

${ }^{25}$ Doha Declaration (n 22).

${ }^{26}$ Hoen (2016).
} 


\subsection{Remedies to Data Exclusivity Barriers and Compulsory Licensing}

Some countries have introduced waivers to data exclusivity, which can be invoked to ensure that the regulatory authority can proceed with the registration of a generic product produced or imported under a compulsory licence. Countries that have such data exclusivity waivers include Malaysia, Chili and Colombia. ${ }^{27}$

Section 5 of the Malaysia 2011 Directive of Data Exclusivity, ${ }^{28}$ entitled Non-Application of

Data Exclusivity, provides that Nothing in the Data Exclusivity shall:

(i) apply to situations where compulsory licenses have been issued or the implementation of any other measures consistent with the need to protect public health and ensure access for all; or

(ii) prevent the Government from taking any necessary action to protect public health, national security, non-commercial public use, national emergency, public health crisis or other extremely urgent circumstances declared by the Government.

In Chile, Article 91 of Law 19.996, as amended in $2012,{ }^{29}$ provides that test data exclusivity shall not be applied:

(b) Where, for reasons of public health, national security, public non-commercial use, national emergency or other circumstances of extreme urgency declared by the competent authority, it is justified to terminate the protection referred in Article 89' [on test data exclusivity].

(c) The pharmaceutical or agrochemical product is the subject of a compulsory license in conformity with the provisions of this law.

In Colombia, Article 4 of Decree 2085 of 2002 on data exclusivity provides that, 'The protection referred to in this Decree does not apply in the following cases [...] c) where necessary to protect the public, as qualified by the Ministry of Health'.

In the absence of such a waiver, countries have found it difficult to make effective use of compulsory licensing. See Box 1.

\section{Box 1: Case of Romania and Malaysia}

In 2015 the World Health Organization (WHO) set the target of eliminating hepatitis C (HCV) as a public health threat by 2030. To reach this goal, prevention and treatment are necessary. People infected with HCV need a 12 -week course of antiviral treatment. In countries that cannot access generic supply of HCV medicines, the price of the originator product may be a barrier to reaching the elimination target.

In 2016, the government of Romania contemplated use of a compulsory licence for sofosbuvir, an essential medicine for the treatment of $\mathrm{HCV}$.

(continued)

\footnotetext{
${ }^{27}$ Hoen et al. (2017). https://joppp.biomedcentral.com/articles/10.1186/s40545-017-0107-9.

${ }^{28} \mathrm{https}: / /$ npra.gov.my/images/reg-info/DataEx/Directive_on_DE.pdf.

${ }^{29} \mathrm{http}: / / \mathrm{www}$.wipo.int/edocs/lexdocs/laws/en/cl/cl042en.pdf.
} 
Box 1 (continued)

Sofosbuvir was only available from the originator company at a price of around 50,000 euro for a 12-week treatment. ${ }^{30}$ However, EU data exclusivity for the product will not expire before 2022. This means that, even with a compulsory licence, the registration of a generic version of sofosbuvir would be prohibited until that date. ${ }^{31}$ Further, the EU market exclusivity for sofosbuvir expires at the earliest in 2024. Romania, like any other EU Member State, cannot give effect to a compulsory licence during the data and market exclusivity terms.

In contrast, when Malaysia issued a compulsory licence for sofosbuvir in $2017^{32}$ it was not hampered to register the generic product due to its legal waiver to data exclusivity (see Sect. 6.3).

\subsection{Data Exclusivity Waivers in FTAs}

The US does not have an explicit exception to data exclusivity for medical products. However, the consequence of data exclusivity for the effective use of TRIPS flexibilities was recognised in 2007 when the New Trade Policy in the US explicitly authorised a public health exception to data/market exclusivity in the event of a compulsory licence or other public health need. This flexibility in implementing data exclusivity was included in several US developing-country FTAs, including with Colombia, Panama, and Peru. This implementation flexibility reads:

For pharmaceutical products, Article 16.10.2(e)(i) provides an exception to the data exclusivity obligations for measures to protect public health in accordance with the Declaration on the TRIPS Agreement and Public Health (WT/MIN(01)/DEC/2) (the 'Doha Declaration'). Thus, where a Party issues a compulsory licence in accordance with Article 31 of the TRIPS Agreement and the Doha Declaration, the data exclusivity obligations in Chapter Sixteen will not prevent the adoption or implementation of such a public health measure. In addition, in a case in which there is no patent on the pharmaceutical product, and, therefore, no need to issue a compulsory licence, the data exclusivity obligations in Chapter Sixteen will not prevent the adoption or implementation of such a measure. ${ }^{33}$

Certain trade agreements the EU is a party to establish that, in regard to test data, parties may provide exceptions to exclusivity for reasons of public interest and for

\footnotetext{
${ }^{30} \mathrm{Paun}$ (2016) http://www.politico.eu/pro/high-drug-prices-romania-changes-patents-hepatitis/.

${ }^{31}$ European Medicines Agency, 'Marketing authorization' Europa http://www.ema.europa.eu/ema/ index.jsp?curl=pages/regulation/general/general_content_001595.jsp\& $\mathrm{mid}=\mathrm{WC0b} 01 \mathrm{ac} 0580 \mathrm{~b} 18 \mathrm{a} 3 \mathrm{~d} \#$.

${ }^{32}$ Hoen (2018) https://medicineslawandpolicy.org/2018/04/the-power-of-trips-flexibilities-in-medi cines-procurement/.

${ }^{33}$ Office of the U.S. Trade Representative, Statement of Administration Action (2007) https://ustr. gov/archive/assets/Trade_Agreements/Bilateral/Peru_TPA/PTPA_Implementing_Legislation_ Supporting_Documentation/asset_upload_file194_15341.pdf.
} 
emergency situations. An example is the EU-Peru Agreement. Article 231 (4) provides that ' $[\mathrm{t}] \mathrm{he}$ Parties may regulate exceptions for reasons of public interest, situations of national emergency or extreme urgency, when it is necessary to allow access to those data to third parties. ${ }^{34}$ The implication of this is that the EU and Peru, both party to this agreement, may provide and use data exclusivity waivers to ensure effective use of compulsory licence. The waiver may also be relevant for non-patented products that still have a monopoly in the market because of data exclusivity. To take advantage of this provision, the party countries would need to provide for a data exclusivity waiver in their regulations.

\subsection{EU Medicines Regulation and Compulsory Licensing}

EU law does not yet provide a safety valve to data exclusivity to allow registration of a competitor product in the EU. This became apparent during the h5n 1 virus (avian influenza) outbreak in 2006, when the threat of a shortage of the antiviral oseltamivir (Tamiflu) signalled the need for an emergency compulsory licence in countries that wanted to ensure sufficient stockpile of the antiviral medicine. The European Generic Association had inquired as to the options under EU law to provide generic oseltamivir for epidemic preparedness purposes, but the European Commission informed them that: ${ }^{35}$

National emergency provisions in an EU Member State may allow the granting of a compulsory patent licence which would allow a generic or other company to use the patented product in the Member State in question.

However, the Community pharmaceutical acquis does not currently contain any provision allowing the waiver of the rules on data exclusivity and marketing protection periods described above in the case of a national or an EU-wide emergency.

Before expiry of the data exclusivity and marketing protection periods provided for by the European pharmaceutical legislation, applicants for a generic marketing authorisation have to either (1) provide the relevant authority with the required documentation on preclinical tests and clinical trials or (2) confirm that the marketing authorisation holder has consented to the use of the required documentation by the applicant.

The Commission response confirms the lack of public health safeguards in European pharmaceutical legislation. Even in cases of an urgent need or emergency situations, no data exclusivity waiver exists that can be applied by EU member states.

\footnotetext{
${ }^{34}$ Trade Agreement between the European Union and its Member States, of the one part, and Colombia and Peru, of the other part [2012] L354/3.

${ }^{35}$ European Commission, 'Letter from the European Commission to Mr. Greg Perry, EGA-European Generic Medicines Association on the subject of Tamiflu application and data exclusivity in an emergency compulsory license situation' (Brussels, 2006) http://www.cptech.org/ ip/health/dataexcl/ec-de-tamiflu.pdf.
} 


\subsection{EU Data Exclusivity Waiver and Compulsory Licence for Export}

The one waiver to data exclusivity in the EU is only foreseen in cases of compulsory licensing for manufacturing a product for export outside the EU but not to enable effective use of compulsory licensing or other measures to protect public health within EU member states. ${ }^{36,37}$ Article 18 of the EU Regulation addresses the situation in which the applicant for a compulsory licence to manufacture medicines in an EU Member State for export outside the EU may use the scientific opinion procedure of the European Medicines Agency ${ }^{38,39}$ or any similar national procedures intended exclusively for markets outside the EU. These scientific opinions provide a benefit/risk analysis of a medicine, designed to facilitate registration in importing countries. ${ }^{40}$ The procedure provides waivers to data exclusivity rules necessary to obtain such opinions from the EMA or national authorities. ${ }^{41}$

\subsection{Data Exclusivity Waivers in Voluntary Patent Licences}

The need to provide data exclusivity waivers to ensure effective availability of generic medicines is often recognised in voluntary licences. For example, all Medicines Patent Pool ${ }^{42}$ (MPP) licences include a data exclusivity waiver to facilitate

\footnotetext{
${ }^{36}$ Regulation 816/2006 on Compulsory Licensing of Patents Relating to the Manufacture of Pharmaceutical Products for Export to Countries with Public Health Problems [2006] OJ L157/1.

${ }^{37}$ This regulation implements the WTO 'August 30, 2003 decision', which provided a waiver to the TRIPS Article 31(f) requirement that production under a compulsory licence be predominantly for the domestic market. This restriction hampered the use of compulsory licensing by countries that were dependent on the importation of medicines. The 30 August 2003 waiver became a permanent amendment of the TRIPS Agreement in 2017 (see: WTO, 'WTO Members Welcome Entry Into Force of Amendment to Ease Access to Medicines' (30 January 2017) https://www.wto.org/ english/news_e/news17_e/heal_30jan17_e.htm.

${ }^{38}$ Article 58 of Regulation (EC) No 726/2004.

${ }^{39}$ Committee for Medicinal Products for Human Use (CHMP) (European Medicines Agency, 17 November 2005). http://www.ema.europa.eu/docs/en_GB/document_library/Scientific_guide line/2009/09/WC500003883.pdf.

${ }^{40}$ European Medicines Agency, 'Medicines for use outside the European Union'. https://www.ema. europa.eu/en/human-regulatory/marketing-authorisation/medicines-use-outside-european-union.

${ }^{41}$ Regulation (EC) No 816/2006 of the European Parliament and of the Council of 17 May 2006 on compulsory licensing of patents relating to the manufacture of pharmaceutical products for export to countries with public health problems. Article 18(2) reads: "If a request for any of the above procedures concerns a product which is a generic of a reference medicinal product which is or has been authorised under Article 6 of Directive 2001/83/EC, the protection periods set out in Article 14 (11) of Regulation (EC) No 726/2004 and in Articles 10(1) and 10(5) of Directive 2001/83/EC shall not apply".

${ }^{42}$ Medicines Patent Pool http://www.medicinespatentpool.org/.
} 
regulatory approval of generics manufactured by MPP licensees in the territories that grant test data exclusivity. For instance, Guatemala is included in the territory of the MPP licences with ViiV Healthcare for paediatric formulations of dolutegravir (DTG) and for adult formulations of DTG and abacavir (ABC), both treatments for HIV. The licences specifically state that:

ViiV shall provide any Sublicensee with NCE [New Chemical Entity] exclusivity or other regulatory exclusivity waivers to the extent required by the applicable regulatory authorities in order to manufacture or sell Product in the Territory in accordance with the terms of the Sublicence. ViiV shall further provide to any Sublicensee such consents which it has the legal capacity to give as are necessary to enable such Sublicensee to perform its obligations. $^{43}$

\section{Box 2: Data Exclusivity Waiver in Voluntary Licences: The Case of Guatemala}

The HIV treatment formulations of DTG $50 \mathrm{mg}$ and ABC/DTG/3TC 600/50/ $300 \mathrm{mg}$ are protected by test data exclusivity in Guatemala until 11 November 2020 and 29 November 2021 respectively. ${ }^{44}$ However, MPP licensees will be able to register and market generic versions of these formulations in Guatemala before the expiration of these rights, based on the waiver included in the MPP licence agreements.

Drug company Gilead has included the following waiver of data exclusivity in its licence agreements for $\mathrm{HCV}$ treatment sofosbuvir:

Gilead agrees to provide Licensee with NCE Exclusivity, or other regulatory exclusivity, waivers as may be required by the applicable regulatory authorities in order to manufacture or sell Product in the Territory, provided such manufacture and sale by Licensee is compliant with the terms and conditions of this Agreement. Licensee agrees not to pursue or obtain regulatory exclusivity on any Product in any country within the Territory. ${ }^{45}$

Even though Gilead obtained test data exclusivity for sofosbuvir $400 \mathrm{mg}$ until 14 July 2021 in Guatemala, for instance, Gilead licensees should not be barred from registering and selling generic versions of sofosbuvir 400mg during this data exclusivity period in Guatemala, which is included in the license territory.

\footnotetext{
${ }^{43}$ Medicines Patent Pool, 'Products Licensed: ViiV' https://medicinespatentpool.org/what-we-do/ global-licence-overview/licences-in-the-mpp/?patent_holder=2718 Link Does Not Work.

${ }^{44}$ Medicines Patent Pool, 'MedsPaL The Medicines Patent and Licences Database'. https://www. medspal.org.

${ }^{45}$ Gilead Sciences (15 September 2014) https://www.gilead.com/ /media/files/pdfs/other/2014_ original_hcv_licensing_agreement.pdf?la=en.
} 


\subsection{Public Health Measures, Data Exclusivity and Competition Law}

Some scholars have argued that the issuance of a compulsory licence for public interest reasons creates the obligation for the patent holder to provide a waiver to data exclusivity. ${ }^{46}$ A company holding a dominant position in the market that denies access to the data held by the regulatory authority in the case of a compulsory licence is likely to be viewed as abusive under competition law since national authorities have already decided that the public interest requires an additional product on the market. However, enforcing this position will likely lead to protracted legal procedures and delays in the availability of the medicine for which the compulsory licence was requested.

\subsection{EU Law Needs an Explicit Data Exclusivity Waiver}

It would be desirable to introduce explicit data and market exclusivity waivers in national legislation. This is particularly important in the EU, now that European countries have indicated that they lack the negotiating power to obtain good results in price negotiations with pharmaceutical companies concerning patented products and several EU countries are exploring the use of compulsory licensing to strengthen this position. $^{47}$

The following amendment to the EU medicines regulation would introduce a waiver to data exclusivity similar to the one contained in the Regulation on compulsory licensing for export: ${ }^{48,49}$

The protection periods set out in article 14 (11) of Regulation 726/2004 shall not apply in cases where it is necessary to allow access to and the use of pharmaceutical test data to register a generic of a reference medicinal product, which is or has been authorised under article 6 of Directive 2001/83/EC, for reasons of public interest including public health, in case of compulsory licensing of patents, including for public non-commercial use, and in situations of national emergency or extreme urgency.

\footnotetext{
${ }^{46}$ Junod (29 January 2019) https://www.publiceye.ch/fileadmin/doc/Medikamente/ValerieJunod_ Legal-Analysis-CL_20190129.pdf.

${ }^{47}$ Rumney (Public Finance International, 16 January 2017). https://www.publicfinancefocus.org/ news/2017/01/drug-manufacturers-have-too-much-power-price-negotiations-says-oecd.

${ }^{48}$ Regulation (EC) No 816/2006 of the European Parliament and of the Council of 17 May 2006 on compulsory licensing of patents relating to the manufacture of pharmaceutical products for export to countries with public health problems.

${ }^{49}$ Hoen et al. (2017).
} 


\section{Conclusion and Recommendations}

The TRIPS Agreement provides much flexibility for WTO members to design a test data protection regimes conducive to public health.

Where possible, countries should refrain from implementing data exclusivity and instead use the flexibility offered to them in the TRIPS agreement to provide data protection for certain types of data only and without granting exclusive rights to the originator of the data.

Safeguards need to be in place to ensure that data remains available for legitimate public health functions including the assessment of efficacy and safety of needed products. Countries that have a data exclusivity regime should have the option to use waivers to data (and market) exclusivity for effective use of measures such as compulsory licensing, to protect public health.

There are different ways in which undisclosed test data can be protected, including: protecting it against dishonest commercial practices, but allowing its use to register a generic product, ${ }^{50}$ permitting generic reliance on the test data but with compensation to the entity that originally generated the data. ${ }^{51}$ Countries should consider replacing data exclusivity regimes with data protection regimes that acknowledge the investment made to generate data but do not allow the investor to exclude others from using the data. Under a data compensation regime, the registration of a generic medicine or biosimilar medicine is considered fair commercial use. The originator company that made the investment that was needed to generate the data will receive adequate remuneration for the use of the data but cannot prevent its necessary use by the medicines agency to perform its public health duties. The data compensation regime could be proposed as an alternative to data exclusivity demands in trade negotiations.

\section{References}

Agreement on Trade-Related Aspects of Intellectual Property Rights (Apr. 15, 1994) Marrakesh Agreement Establishing the World Trade Organization, Annex 1C, The Legal Texts: The Results of the Uruguay Round of Multilateral Trade Negotiations 320 (1999), 1869 U.N.T.S. 299, 33 I.L.M. 1197 (1994)

Code de la propriété intellectuelle (version consolidée au 9 octobre 2016) Article L613-16

Commission on Intellectual Property Rights, Innovation and Public Health, Public Health, Innovation and Intellectual Property Rights (World Health Organization, 2006)

Committee for Medicinal Products for Human Use (CHMP), 'Guideline on Procedural Aspects Regarding a CHMP Scientific Opinion in the Context of Cooperation with the World Health Organisation (WHO) for the Evaluation of Medicinal Products Intended Exclusively for Markets Outside the Community' (European Medicines Agency, 17 November 2005). http://www.

\footnotetext{
${ }^{50}$ Correa (2002).

${ }^{51}$ For example, in the US, Knowledge Ecology International has proposed a cost sharing model. See for details: Sanjuan et al. (2006), p. 1.
} 
ema.europa.eu/docs/en_GB/document_library/Scientific_guideline/2009/09/WC500003883. pdf. Last accessed 23 Feb 2021

Copenhagen Economics, Study on the economic impact of supplementary protection certificates, pharmaceutical incentives and rewards in Europe (European Commission, May 2018). https:// ec.europa.eu/health/sites/health/files/human-use/docs/pharmaceuticals_incentives_study_en. pdf. Last accessed 22 Feb 2021

Correa CM (2002) Protection of data submitted for the registration of pharmaceuticals: implementing the standards of the TRIPS Agreement. South Centre, Geneva. http://apps.who. int/medicinedocs/en/d/Jh3009ae/. Last accessed 23 Feb 2021

Council of the EU (17 June 2016) Council conclusions on strengthening the balance in the pharmaceutical systems in the EU and its Member States. https://www.consilium.europa.eu/ en/press/press-releases/2016/06/17/epsco-conclusions-balance-pharmaceutical-system/. Last accessed 22 Feb 2021

Declaration on the TRIPS agreement and public health (14 November 2001) WT/MIN(01)/DEC/2 https://www.wto.org/english/thewto_e/minist_e/min01_e/mindecl_trips_e.htm

European Commission, 'Letter from the European Commission to Mr. Greg Perry, EGA-European Generic Medicines Association on the subject of Tamiflu application and data exclusivity in an emergency compulsory license situation' (Brussels, 2006). http://www.cptech.org/ip/health/ dataexcl/ec-de-tamiflu.pdf. Last accessed 23 Feb 2021

European Medicines Agency, 'Marketing authorization' Europa http://www.ema.europa.eu/ema/ index.jsp?curl=pages/regulation/general/general_content_001595.jsp\& mid=WC0b01ac0580b18a3d\#. Last accessed 23 February 2021

European Medicines Agency, 'Medicines for use outside the European Union' https://www.ema. europa.eu/en/human-regulatory/marketing-authorisation/medicines-use-outside-europeanunion. Last accessed 23 Feb 2021

European Medicines Agency and the European Commission, Biosimilars in the EU: Information guide for healthcare professionals (European Medicines Agency, 2019). https://www.ema. europa.eu/en/documents/leaflet/biosimilars-eu-information-guide-healthcare-professionals_en. pdf. Last accessed 22 Feb 2021

Federal Trade Commission (June 2009) Emerging health care issues: follow-on biologic drug competition. https://www.ftc.gov/sites/default/files/documents/reports/emerging-health-careissues-follow-biologic-drug-competition-federal-trade-commission-report/ p083901biologicsreport.pdf. Last accessed 22 Feb 2021

Gilead Sciences, 'Licence Agreement' (15 September 2014). https://www.gilead.com/ /media/ files/pdfs/other/2014_original_hcv_licensing_agreement.pdf?la=en. Last accessed 23 Feb 2021

Hoen E't (2016) private patents and public health: changing intellectual property rules for access to medicines. AMB Press, Health Action International, The Netherlands

Hoen E, 'The Power of TRIPS Flexibilities in Medicines Procurement' (Medicines Law \& Policy, 9 April 2018). https://medicineslawandpolicy.org/2018/04/the-power-of-trips-flexibilities-inmedicines-procurement/. Last accessed 23 Feb 2021

Hoen E't FM, Boulet P, Baker BK (2017) Data exclusivity exceptions and compulsory licensing to promote generic medicines in the European Union: a proposal for greater coherence in European pharmaceutical legislation. JOPPP 10. https://joppp.biomedcentral.com/articles/10.1186/ s40545-017-0107-9. Last accessed 23 Feb 2021

Junod V, 'Legal analysis: the interface between patent protection and data exclusivity - the issue of compulsory licensing in the public interest under Swiss Law' (Public Eye, 29 January 2019). https://www.publiceye.ch/fileadmin/doc/Medikamente/ValerieJunod_Legal-Analysis-CL_ 20190129.pdf. Last accessed 23 Feb 2021

Law No. 19.996 revising Law No. 19.039 on Industrial Property. http://www.wipo.int/edocs/ lexdocs/laws/en/cl/cl042en.pdf. Last accessed 23 February 2021

Lietzan E (2016) The myths of data exclusivity (University of Missouri School of Law). Lewis Clark Law Rev 20:91. https://pdfs.semanticscholar.org/2fdb/ 0784f6fb314cf99063933cb6bfbfae6a7091.pdf. Last accessed 22 February 2021 
Medicines Law \& Policy, How the 'Oxford' Covid-19 vaccine became the 'AstraZeneca' Covid-19 vaccine. https://medicineslawandpolicy.org/useful-resources/briefs/. Last accessed 22 February 2021

Medicines Patent Pool, MedsPaL: The Medicines Patents and Licences Database https://www. medspal.org. Last accessed 23 February 2021

Medicines Patent Pool. http://www.medicinespatentpool.org/. Last accessed 23 February 2021

Medicines Patent Pool 'Products Licensed: ViiV'. https://medicinespatentpool.org/what-we-do/ global-licence-overview/licences-in-the-mpp/?patent_holder=2718. Link Does not Work

Office of the U.S. Trade Representative, Statement of Administration Action (2007). https://ustr. gov/archive/assets/Trade_Agreements/Bilateral/Peru_TPA/PTPA_Implementing_Legislation_ Supporting_Documentation/asset_upload_file194_15341.pdf. Last accessed 23 Feb 2021

Paun C (16 March 2016) 'Skyhigh drug prices made Romania mull unusual path' Politico, http:// www.politico.eu/pro/high-drug-prices-romania-changes-patents-hepatitis/. Last accessed $23 \mathrm{Feb} 2021$

Regulation 816/2006 on Compulsory Licensing of Patents Relating to the Manufacture of Pharmaceutical Products for Export to Countries with Public Health Problems [2006] OJ L157/1

Reichman JH (2009) The international legal status of undisclosed clinical trials data: from private to public goods? Marquette Intellect Property Law Rev 13:17

Rumney E, 'Drug manufacturers have too much power in price negotiations, Says OECD' (Public Finance International, 16 January 2017). https://www.publicfinancefocus.org/news/2017/01/ drug-manufacturers-have-too-much-power-price-negotiations-says-oecd. Last accessed $23 \mathrm{Feb}$ 2021

Sanjuan JR, Love J, Weissman R (2006) Protection of pharmaceutical test data: a policy proposal' KEI Research Paper 2006:1

Technopolis (15 June 2018a) Effects of supplementary protection mechanisms for pharmaceutical products. https://www.technopolis-group.com/report/effects-of-supplementary-protectionmechanisms-for-pharmaceutical-products/. Last accessed 22 Feb 2021

Technopolis (May 2018b) Effects of supplementary protection mechanisms for pharmaceutical products. http://www.technopolis-group.com/wp-content/uploads/2018/06/2718-Technopolisreport-on-supplementary-protection-mechanisms.pdf. Last accessed 22 Feb 2021

The Council for Trips Extension of the Transition Period Under Article 66.1 of the Trips Agreement for Least Developed Country Members for Certain Obligations with Respect to Pharmaceutical Products (6 November 2015), World Trade Organization IP/C/73

Timmermans K (2007) Monopolizing clinical trial data: implications and trends. PLoS Med 4:e2

U.S. Federal Trade Commission, 'Emerging Health Care Issues: Follow-on Biologic Drug Competition' (FTC, June 2009). https://www.ftc.gov/reports/emerging-health-care-issues-followbiologic-drug-competition-federal-trade-commission-report. Last accessed 22 Feb 2021

WHO (2012) WTO, WIPO Trilateral Study Promoting Access to Medical Technologies and Innovation, 64 https://www.wipo.int/policy/en/global_health/trilateral_cooperation.html. Last accessed 22 February 2021

WIPO, 'Meaning of Flexibilities' http://www.wipo.int/ip-development/en/agenda/flexibilities/ meaning_of_flexibilities.html. Last accessed 23 February 2021

WTO, 'WTO Members Welcome Entry Into Force of Amendment to Ease Access to Medicines' (30 January 2017). https://www.wto.org/english/news_e/news17_e/heal_30jan17_e.htm. Last accessed 23 Feb 2021

WTO 'TRIPS Council Discussion on Access to Medicines: Developing Country Group's Paper' (World Trade Organization, 20 June 2001) IP/C/W/296, paras 39-40. https://www.wto.org/ english/tratop_e/trips_e/paper_develop_w296_e.htm. Last accessed 23 Feb 2021 
Open Access This chapter is licensed under the terms of the Creative Commons Attribution 4.0 International License (http://creativecommons.org/licenses/by/4.0/), which permits use, sharing, adaptation, distribution and reproduction in any medium or format, as long as you give appropriate credit to the original author(s) and the source, provide a link to the Creative Commons license and indicate if changes were made.

The images or other third party material in this chapter are included in the chapter's Creative Commons license, unless indicated otherwise in a credit line to the material. If material is not included in the chapter's Creative Commons license and your intended use is not permitted by statutory regulation or exceeds the permitted use, you will need to obtain permission directly from the copyright holder. 